\title{
The impact of EU regulations on the Polish legal system in the field of administrative law. The need to create new, special (untypical) entities in Polish administrative law
}

\author{
P. Bieś-Srokosz' ${ }^{1}$ M. A. Kapustina ${ }^{2}$ \\ ${ }^{1}$ Jan Dlugosz University in Czestochowa, 2/4 Zbierskiego, Poland, 42-200, Częstochowa \\ ${ }^{2}$ Saint-Petersburg State University, 7-9, Universitetskaya nab., St.Petersburg, 199034, Russian Federation
}

For citation: Bieś-Srokosz, Paulina, Kapustina, Mariia A. 2018. “The impact of EU regulations on the Polish legal system in the field of administrative law. The need to create new, special (untypical) entities in Polish administrative law". Vestnik of Saint Petersburg University. Law 4: 605-619. https://doi.org/10.21638/spbu14.2018.411

As an institution, the European Union forces the Member States to adapt to its requirements, which are the fulfilment of its vision of functioning. The Union does not allow the Member State to act contrary to its rules. Anyone who wants to belong to the Union should not the only accent but also implement its provisions in its legal system. This is due to the fact that the Union wants to be one, a common institution, and not a set of countries that are legally different, acting in such a way that they are mutually exclusive. Therefore, in specific sectors, the EU dictates very clear conditions, thus affecting the introduction of specific regulations into a given legal order, even by creating specific entities. And this is the case in Poland. Therefore, the main intention of the authors of the article is to show and characterize very clear EU influence on the creation and operation of new entities in the Polish legal system, in particular in the Polish administrative law. The main emphasis was put on the creation and functioning of government agencies in Poland, which EU regulations have a huge impact, among others due to the transfer of funds for the performance of their individual tasks.

Keywords: European Union, EU regulations, Polish law, uniform regulation, administrative law, special entities in the legal system, public administration entity, cohesion policy programmes.

\section{Introduction}

In the theory of Polish administrative law, there are several definitions of public administration. Regardless of which one of them is right, it must be borne in mind that public administration is a legal, social and political phenomenon. Furthermore, public administration is characterised by the following features: acting on behalf of and on the account of the state or other public entity separate from the state, but exercising some of the state's power; acting in the public interest pursuant to acts of law and within the boundaries stipulated by them; a political nature which involves evaluating the actions taken by administration in

* The co-author, Kapustina Mariia Alexandrovna, acknowledges Saint-Petersburg State University for a research grant 26520757 .

(C) Санкт-Петербургский государственный университет, 2018 
terms of politics. It must be noted, however, that on the one hand, as regards the legal and structural point of view, the characteristic feature of contemporary public administration is the diversity of entities or their legal and organizational forms that perform the functions of administration. On the other hand, the political, economic and social changes of the 1980s contributed to the increased number of public tasks performed by public administration. While the development of new public tasks was justified by the necessity of satisfying increasing social needs, the production of new organizational and legal forms in the administration has been raising certain doubts and reservations. It stems from the fact that a large number of administrative law scholars point out that it is difficult to draw a clear parting line enabling the identification of the entities to perform public tasks.

One should agree that the untypical (specific) public administration entities that function in Polish law have been established by the legislator in order to adjust the state to its new tasks. Those tasks are constantly developing, which is justified by the state's activity towards the society (Knosala 2007, 121). The state's adjustment to the citizens' new needs is connected with both the dynamics of social life, which stems from the processes of Europeanisation and globalisation, as well as with the transfer of legal solutions from other European countries to Poland, that is the application of so-called legal transplants by the legislator. It goes without saying that public administration tasks arise from its essential objective (Longchamps de Bérier 1968, 15; Boć 2003) which involves satisfying a variety of different collective and individual needs present in the lives of particular communities. According to F. Longchamps de Bérier (Longchamps de Bérier 1991, 114), public tasks are rooted in the essential objective and, simultaneously, they correspond with the fragmentary aims of public administration. As a consequence, the objective of administration is, in fact, the public task which reflects the values acknowledged by the legislator. Hence, pursuant to the Polish law, constitutional and statutory regulations are considered the sources of public administration tasks.

It must be borne in mind that only the state can decide about who performs given tasks and what form they should take. As a common good (Trzciński 2005, 452) the state embraces also the institutions which are new organizational forms, their organs, and tasks - public tasks. On the other hand, however, the notion of public task and competence of a public administration organ to perform such a task are reciprocally and inseparably connected categories which determine the legal bases and limits of public administration activity (Rabska 1990,110 ). It can be observed that the state establishes (creates) new organizational and legal forms characteristic of corporate entities. In order to ensure the fulfilment of public tasks, the state shares its power with other entities involved in that activity. The theory describes them as administering entities (Jagielski, Wierzbowski and Wiktorowska 2005, 206). Hence, as early as at this stage of the discussion it must be stated that the purpose of government agencies, as well as the fact that they perform public tasks, are an example of public service in public administration. This view will be supported later in the paper.

The legislator employs untypical organizational and legal forms of public administration for the state establishes new organizational units designed to satisfy social needs. Those untypical entities include government agencies which exemplify how organizational forms of administration can adjust to constantly changing public tasks. The lack of common and uniform regulation that would cover all agencies results from their existing division according to their legal nature. They function both as civil and private law entities. For this reason, they can be regarded as specific public administration entities. 
In the theory of Polish administrative law government agencies are often mistakenly systematized. At first, they can be divided according to their legal and organizational forms. That group includes central organs of public administration, sole-shareholder companies of the State Treasury, and state juridical persons. Secondly, they can be divided according to the type of performed tasks. That group includes fiduciary agencies, intervention agencies, and national reserves agencies. Because of the diversity of agencies, the unification of their formation procedures is not possible. However, the government agencies that operate in the form of state juridical persons are formed by way of an act.

Government agencies are public administration entities which perform a variety of administrative tasks characteristic of both administrative as well as civil law. Government agencies also called as: state agencies, administrative agencies, or just agencies (BieśSrokosz 2016, 9-20). They include the Agency for Restructuring and Modernisation of Agriculture, Material Reserves Agency, Military Property Agency, Agricultural Market Agency, and Polish Agency for Enterprise Development, National Agricultural Support Center. Nevertheless, it must be pointed out that the detailed objective scope of their activity is stipulated by means of statutory or secondary legislation. It means that the legislator decides about what administrative tasks are a given government agency to perform.

It is a well-known fact that public administration tasks result from its essential objective (Longchamps de Bérier 1968, 15; Boć 2003, 15), that is to satisfy various and different collective as well as individual needs present in the lives of particular communities. According to Longchamps (Longchamps de Bérier 1991, 114), public tasks are rooted in the essential objective, and simultaneously, they correspond with the fragmentary aims of public administration. As a consequence, the objective of administration is, in fact, the public task which reflects the values acknowledged by the legislator. Hence, in compliance with the binding Polish law, constitutional and statutory regulations are considered the sources of public administration tasks.

The creation of new organizational and legal forms, both at the level of the EU and the national legal system, does not arouse surprise at the moment, but it still raises a discussion on the need and the essence of their appointment and their functioning. New organizational and legal forms created in public administration, referred to in this article as special (atypical) public administration entities, are an example of the Polish state's response to requirements regulated in European Union law, new public tasks and growing needs of civil society.

The authors of the article will focus their attention largely on the analysis of government agencies in Poland. They are a very controversial example of specific public administration entities.

\section{The impact of EU regulations on the Polish legal system in the field of administrative law: the establishment of new organizational forms of public administration entities}

The political changes in Poland that took place at the end of the $20^{\text {th }}$ century contributed to the establishment of new organizational forms of public administration entities. Their objective was to adapt the administration, its operations, and its organizational forms to perform new public tasks in the area of the economy. The entities operating 
within those new organizational forms were in conflict with the traditional notion of public administration entity. The main objective of this article is the analysis of the legal status of each specific entities of public administration and to draw attention to their eclectic legal character.

\subsection{Differences between "public administration entity" and "special” (untypical) entity of public administration}

The majority of relevant notions and institutions present in Polish administrative law system need to be approached in a new way, for the current approach is to a certain extent out-of-date and may raise doubts. The same holds for the notion of public administration entity. Such a state of affairs may be caused by the structural transformations of the state which continually expands the range of tasks to perform. It may also be a result of the formation of new organizational forms. The Polish theory lacks an unambiguous definition of public administration entity. In the literature on the subject one can find numerous approaches to „public administration entity”. According to W. Dawidowicz, public administration entity is an entity formed (created) and equipped by a legislative act with a number of competencies for the performance of administrative tasks, being at the same time a starting point for the establishment of proper organizational structure necessary to perform those tasks. M. Stahl points out that numerous representatives of the theory (Rabska 1977, 270; Maurer 2003, 230) consider the state the elementary public administration entity (Stahl 2011, 12). It stems from the legal personality of the state and the fact that it is represented by its own organs exercising state power. That power is always of state nature. The state can devolve some power to public administration entities as well as to non-public entities which are legally bound to perform public tasks. Nevertheless, it is organs of those entities that exercise power on behalf of the state and other entities. When it comes to public administration, its organs exercise administrative power pursuant to administrative law provisions (Borkowski 1972, 43; Pulka 1992, 137; Jendrośka 1963, 15). It is, therefore, an inherent feature of public administration entities and activities performed by the organs of those entities (Kasznica 1943, 38).

However, in the $19^{\text {th }}$ and $20^{\text {th }}$ centuries, the scope of the notion of public administration entity was expanded to include not only public administration organs but also entities equipped with legal personality and performing public administration tasks. According to M.Stahl, ,the employment of the notion of public administration entity stemmed from legal reality and the search for forms of decentralization of public tasks while with the increase of the number of state tasks and activities the deconcentration formula was not sufficient anymore and it was necessary to form independent organizational units equipped with separate legal personality" (Stahl 2011, 15). Apart from the notion "public administration entity", there are other similar notions in the literature: public entity, public law entity, administration entity and administering entity. The term "public entity" is wider than the definition of the concept of entity administration. The concept of a public entity is in particular in the acts on public-private partnership and the operations of the entities performing public tasks. The term „public law entity” of a public body is narrower than the concept of scope as an administrative entity. This is due to the list of entities that belong to him. First of all, the basis for determining the public body is the nature of the standards of its establishment and the functions performed. 
The administration entity belongs to the category of "public law entities” which perform public tasks of administrative nature. According to the theory, each entity obliged under statutory provisions to perform public administration tasks is considered an administrative entity. „Public law entity” has been defined in Article 2, Paragraph 1 Subparagraph 4 of the Directive 2014/24/EU of the European Parliament and of the Council of 26 February 2014 on public procurement and repealing Directive 2004/18/EC (Official Journal of the European Union 2014, L 94/65) and in Article 3 Paragraph 4 of the Directive 2014/25/EU of the European Parliament and of the Council of 26 February 2014 on procurement by entities operating in the water, energy, transport and postal services sectors and repealing Directive 2004/17/EC (Official Journal of the European Union 2014, L 94/243). „Public law entities (bodies)” means bodies that have all of the following characteristics: a) they are established for the specific purpose of meeting needs in the general interest, not having an industrial or commercial character; b) they have legal personality; and c) they are financed, for the most part, by the State, regional or local authorities, or by other bodies governed by public law; or are subject to management supervision by those authorities or bodies; or which have an administrative, managerial or supervisory board, more than half of whose members are appointed by the State, regional or local authorities, or by other bodies governed by public law.

And finally, the term of the administrative entity to be understood a class of persons performing public administrative functions in the subjective sense. Yet, further parts of the paper will be devoted only to public administration entities and their characteristic features.

The essential constituents of the notion of public administration entity are: performance of public administration tasks in the public interest, and acting under statutory provisions. It is a wide notion covering all organizational forms of performing public tasks. For this reason, it is not the legal character of a unit's organizational form but the performance of public tasks in the public interest that plays an important role. It must be noted that public administration entities have rights and obligations of administrative nature, stemming from statutory regulations. When the viewed from that angle, the notion covers the following entities: government administration entities, decentralized administration entities, and authorized private law entities.

An organizational unit can be categorized as a public administration entity if its exclusive or main activity involves performing public tasks. It is a sine qua non condition. Thus the entities formed pursuant to private law (e. g. limited liability companies and joint stock companies), or the entities in which majority interest belongs to public law institutions, may be classified as public administration entities if they meet the aforementioned sine qua non condition. It is, however, important to pay attention to the problem of how to classify a given organizational unit under a given group of public administration entities. One must bear in mind all conditions determining the participation of those units in the performance of public administration tasks in a wider and wider scope. All in all, one should consider the notion of public administration entity in the strict sense limiting the range of entities to the ones functioning and acting pursuant to public law.

Taking into account the diverse standpoints advocated by theoreticians, it must be noted that some of them consider "administering entity” a more suitable term. It stems from the fact that on the doctrinal plane the term has become an equivalent of the notion of the public administration system in the functional sense (Stahl 2011, 25). The term "ad- 
ministering entity" encompasses a group of entities included among public administration apparatus and situated outside the structure of the administration, regardless of whether they perform functions of ruling nature or otherwise. However, it must be pointed out that the list of those entities is non-exhaustive. The diversity of administering entities leads to chaos within administrative law system, which in turn leads to problems that are at times difficult to solve (Zimmermann 2006, 103). For this reason, attention must be paid to the fact that the legislator continuously creates new notions as well as new organizational forms classifying them as "untypical public administration entities", for they do not fit within the traditional notion of public administration entity due to their legal structure.

Again, it must be stressed that the notion of public administration entity, as well as the conditions for considering an entity one, depend on several factors. Firstly, one must decide whether to define a public administration entity in the wide or the strict sense. Secondly, a given entity should be considered a public administration entity if it is a part of the public administration apparatus and meets essential conditions. Using the phrase 'meets essential conditions' it must be borne in mind that the public administration entity performs public tasks in the public interest, makes use of power while performing public tasks, is formed in compliance with a legislative act or other normative act, and is subject to supervision by state organs.

It is stressed in the literature that the continuous changes of the society's needs in modern states contribute to the increase of the number of tasks of diverse legal nature. As a consequence, public administration is faced with the problem of how to perform those tasks. The problem entails numerous political, organizational, praxeological, personnel, and legal-structural issues. The latter deserves a closer look, for it concerns organizational forms of performing public tasks, and adaptation of those forms to new needs (Jagielski, Wierzbowski and Wiktorowska 2005, 203). The subjective catalogue of organizational units performing public administration tasks is continuously updated. It stems from the formation of new organizational units that do not fit within the traditional notion of public administration entity.

As it has already been said, the political changes that took place at the end of the $20^{\text {th }}$ century contributed to the establishment of new organizational forms of public administration entities. Their objective was to adapt the administration, its operations, and its organizational forms to perform new public tasks in the area of the economy. The entities operating within those new organizational forms were in conflict with the traditional notion of public administration entity. They include public foundations, funds, government agencies, the National Bank of Poland, and the Polish Post, among others. As to public foundations, currently, there are three foundations of that kind: National Ossolinski Institute, Public Opinion Research Center, and Kórnik Institute. Each one of those public law foundations has been established by way of a given legislative act and performs its public tasks pursuant to the provisions of that act. It must be stressed however that those entities acquire legal personality not under their acts but with the entry to the National Court Register. According to $\mathrm{H}$. Cioch, the provisions of the Act on foundations are not applicable to public law foundations established under separate acts. The aforementioned provisions concern private law foundations established by way of foundational acts. It is justifiable therefore to question such regulations, for the discussed entities should acquire legal personality by way of a given legislative act. They perform public tasks falling within the scope of tasks generally stipulated by the act on foundations. Supervision over the 
operations and tasks performed by those entities is exercised by organs of government administration, that is the competent minister and the Prime Minister (as regards Public Opinion Research Center). Simultaneously, those organs are authorised to equip foundations with statutes and to revoke decisions issued by organs of foundations (if those decisions are in conflict with legal regulations or a given statute).

The discussion of specific public administration entities will be focused first on the National Bank of Poland's position within the legal system. That entity is included among specific entities, for, on the one hand, it displays features of an economic entity, while on the other it is the state's central bank which is at the same time the bank authorised to issue banknotes, and the bank of other banks. Pursuant to Article 52 Paragraph 4 of the Act on the National Bank of Poland, the Bank can possess and trade in foreign currencies on its own behalf, on its own account, and on account of other entities. The bank is also allowed to perform activities concerning foreign currency trading nationally and abroad, giving and taking foreign loans, granting and taking bank sureties and guarantees in international trade.

The Polish Post is another entity characterized by a specific legal status. Its operations involve conducting a business activity that consists of providing postal services nationally and abroad. The activity called "postal activity” is regulated in the Act of $23^{\text {rd }}$ November 2012 on Postal Law. Postal services involve a variety of commercial activities performed jointly or separately which include receiving, sorting and delivering addressed mail and unaddressed advertising mail, translocating parcels and unaddressed advertising mail, sending mail by means of electronic communication if at the stage of registration, translocation or delivery it takes the physical form of letter mail; running exchange offices enabling the clients to send and receive correspondence, and to place and cash postal orders.

The establishment of new forms of organizational units intended for satisfying social needs by the state forces the legislator to employ untypical organizational and legal forms. Those specific entities include also agencies which can serve as an example of the adaptation of organizational forms of administration to constantly changing public tasks. The lack of common and uniform legal regulations concerning all agencies stems from the existing classification of those entities according to their legal nature. They can act as civil as well as public law entities.

In the theory of administrative law, agencies are often wrongly systematized. They can be divided according to their legal and organizational form. Because of the diversity of agencies, the unification of their formation procedures is not possible. Some of the agencies functioning as sole-shareholder companies of the State Treasury are formed by way of a notarial deed whereas other ones by way of a legislative act. The division of agencies according to formation procedure and legal basis makes it impossible to unambiguously classify them as public administration entities organized as public law entities (administrative offices and state juridical persons) or private law entities (sole-shareholder companies of the State Treasury). The doubts concerning the proper classification of agencies among those entities stem from proper defining, for that is what enables one to place them among public or private entities. What is more, the actions undertaken by those entities take legal forms characteristic of both public and private law. In general, agencies can be considered untypical administering entities because of their eclectic legal nature which manifests itself in a mixture of administrative, civil and financial forms of organization as well as in the direct implementation of economic and social policies by the state (Pawłowicz 2001, 139). 
The foregoing analysis of Polish administrative law theory along with selected legal acts allows the conclusion that in the current legal situation the basic notions of administrative law need updating. In other words, administrative law (and the administration itself) should be adapted to constantly changing social needs which force the state to create new organizational and legal forms. As a consequence, what is formed are organizations (institutions) derivative of typical public administration entities, though displaying elements of novelty. That is what makes them untypical (specific). It seems reasonable, however, to reflect on why the legislator forms them, for it is not always justifiable. Sometimes the Polish legislator senselessly transfers forms functioning in other countries into the Polish legal system forgetting about peculiarities of different systems. Hence some of the organizations (institutions) are in advance doomed to failure or inefficiency in performing the tasks devolved upon them. It is therefore important to reach harmony between the state, its legal system, and satisfying needs of modern society.

By explicitly distinguishing the features of specific public administration entities, it should be noted that each of them has legal personality. This person is given by way of a legal act. Thanks to that they can incur legal obligations in their name and on their account. They can also, but if a special rule so provides, lead economic activity. Economic activity does not contribute to the fact that these entities be considered private and to have been entered into the National Court Register. This activity should be carried out additionally and the funds obtained should be transferred to the State Treasury. A characteristic feature of these entities is that they use various legal forms of action. These legal forms have got the public and private character. Interestingly, most of the special public administration entities use legal forms of private action, i.e. a civil law contract (Bieś-Srokosz 2018, 190-196). Their immanent feature is also the performance of tasks with a specific subject range. As can be seen, most of these tasks is aimed at the implementation of tasks in the field of economy or military. Importantly, the activities of each specific entity are regulated by a specific legal act in which the basic operating principles, financial economy, authorities, supervision and control over its activity are defined.

\subsection{The impact of EU regulations on the creation of government agencies under cohesion policy}

The appearance of new organizational and legal forms, both at European and national levels, does not come as a surprise nowadays. Yet it is debatable whether they are absolutely necessary. New organizational and legal forms of public administration, referred to in the paper as specific (untypical) public administration bodies, are an example of the Polish state's reaction to the requirements stipulated in the EU law, new public tasks, and growing needs of the civil society. It should be stressed that Polish government agencies are not and will never be the same as or similar to the EU agencies, neither with regard to the performed tasks nor the status, the operations and responsibilities (Chamon 2010, 282). Both the Polish government agencies and the EU agencies do have a legal personality, but it is the only thing they actually have in common.

Government agencies (also called administrative or state agencies) are an example of specific public administration bodies. They have been created to perform specific public tasks. First Polish government agencies, the Agency for Restructuring and Modernisation of Agriculture and the Agricultural Property Agency, were set up at the beginning of the 
1990s. In the following years leading up to 2008, the five remaining agencies were established: Agricultural Market Agency, Material Reserves Agency, Military Property Agency, Military Housing Agency, and Polish Agency for Enterprise Development. In 2015 the Military Property Agency and the Military Housing Agency were merged into one agency called exactly the same as the former. Changes in how Polish government agencies function are still in progress. In September 2017 the Agricultural Property Agency and the Agricultural Market Agency were transformed into a new government agency: National Centre for Agriculture Support (own translation). Some of the Agricultural Market Agency's duties are transferred to the Agency for Restructuring and Modernisation of Agriculture.

However, bearing in mind the rationale for establishing such agencies as the Agency for Restructuring and Modernisation of Agriculture, the Agricultural Market Agency, and the Polish Agency for Enterprise Development, it must be noted that they were established as a result of adjusting Polish law to the requirements set by EU bodies. Those agencies can be called implementing agencies, for example, Polish Agency for Enterprise Development as an implementing body; Agricultural Market Agency as an intermediate body or beneficiary. Though the Agency for Restructuring and Modernisation of Agriculture and the Agricultural Market Agency comprised a group of payment government agencies. The definition of payment agencies is stipulated in Article 5 of the Regulation (EU) No 1306/2013 of the European Parliament and of the Council of 17 December 2013 on the financing, management and monitoring of the common agricultural policy and repealing Council Regulations (EEC) No 352/78, (EC) No 165/94, (EC) No 2799/98, (EC) No 814/2000, (EC) No 1290/2005 and (EC) No 485/2008 (Official Journal of the European Union L/2013/347). As regards the implementing agencies, it should be stressed that their chief activity was to provide certain entities with EU funds-based financial aid as a part of particular implementation programmes. At the moment financial aid comes from the EU funds granted for the years $2014-2020$ as a part of so-called financial perspective, that is a multiannual financial framework.

2.2.1. Financial perspectives for the years 2014-2020. Pursuant to Article 312 of the Treaty of Lisbon (The Treaty on the Functioning of the European Union of 26 October 2012. Official Journal of the European Union C/2012/326), multiannual financial frameworks are to guarantee that the EU expenditures are systematized and remain within the EU's resources. Financial frameworks should be set for at least five years. They stipulate the maximum annual amount ('ceiling') of funds intended for commitment appropriations in particular expenditure groups ('headings') and payment appropriations. The headings correspond to main areas of the EU's activity. Expenditures included in a financial perspective are divided into groups. Each group has its expenditure ceiling set for a given budget year. The maximum amount of payment is stipulated both in euros and as a proportion of the EU's gross national income (GNI). The amount of expenditure stipulated in a given perspective is annually updated with regard to fluctuation in prices and GNI. However, a line of distinction should be drawn between financial perspectives and annual budgets. What differentiates them from one another is the lack of income, and the specification of expenditures by means of limits set for particular expenditure groups, which allows certain freedom when planning the number of expenditures in particular groups (www.polskawue.gov.pl). 
2.2.1.1. Multiannual Financial Frameworks. The current MFF is divided into six expenditure categories ('headings'): "Smart and Inclusive Growth", "Sustainable Growth: Natural Resources", "Security and Citizenship", "Global Europe”, "Administration", and "Compensations". For the period 2014-2020, the MFF sets a maximum amount of EUR 960 billion for commitment appropriations and EUR 908 billion for payment appropriations (in 2013 prices). In this period the biggest emphasis is placed on the economic support, employment, and competitiveness for the development within the framework of "Europe 2020" strategy. The MFF sets the amount of EUR 325.1 billion for cohesion policy and EUR 373.2 billion for the development of agriculture (mainly for direct subsidies and market measures). According to the report on the EU budget for the years 2014-2020, Poland has received somewhat more funds compared to the years 2007-2013, that is EUR 105.8 billion. 72.9 billion is intended for the cohesion policy and 28.5 billion for agriculture (Mikos-Sitek 2012, 12).

2.2.1.2. Cohesion policy programmes in Poland. It is mandatory for member states of the EU to have an appropriate system for funds control and management. Hence Poland had to adapt its legal system so that it complied with the EU requirements. The same held for legal and organizational forms (institutions) that had to be ready to perform tasks regarding particular EU programmes. In the Polish legal system, those matters are currently stipulated, inter alia, in the Act of 11 July 2014 on principles governing the implementation of cohesion policy programmes financed within the framework of financial perspective for the years 2014-2020 (Journal of Laws from 2014, item 1146). The act's role is to apply, inter alia, the Regulation (EU) No 1303/2013 of the European Parliament and of the Council of 17 December 2013 laying down common provisions on the European Regional Development Fund, the European Social Fund, the Cohesion Fund, the European Agricultural Fund for Rural Development and the European Maritime and Fisheries Fund and laying down general provisions on the European Regional Development Fund, the European Social Fund, the Cohesion Fund and the European Maritime and Fisheries Fund and repealing Council Regulation (EC) No 1083/2006 (Official Journal of the European Union $\mathrm{L} / 2013 / 347$ ).

The Act stipulates the principles governing the implementation of cohesion policy programmes financed within the framework of financial perspective for the years 20142020, bodies taking part in that implementation and conditions of cooperation between them. The cohesion policy implementation process consists of three main levels: coordination, management, and implementation. The coordination consists of: 1) representing the Republic of Poland in relations with the European Commission as regards the matters related to the implementation of the partnership agreement; 2) granting, suspending or withdrawing designation; 3 ) issuing guidelines regarding the implementation of structural funds and the Cohesion Fund hereinafter referred to as „horizontal guidelines”; 4) monitoring the implementation of operational programmes; 5) determining financial and material objectives of expenditures incurred within the framework of operational programmes for subsequent years, and monitoring the implementation of those objectives in the financial perspective for the years 2014-2020; 6) ensuring information and promotion system (including a web portal) devoted to operational programmes. Article 4 Paragraph 2 of on principles governing the implementation of cohesion policy programmes financed within the framework of financial perspective for the years 2014-2020. 
The management pursuant to Article 9 Paragraph 1 the implementing body is: 1) the minister competent for regional development - as regards national operational programmes and the programme ETC if a managing body has been established on the territory of the Republic of Poland; 2) voivodeship government - as regards regional operational programmes.

The coordination of operational programmes implementation is the duty of the minister competent for regional development. The same minister is responsible for managing all national operational programmes with the participation of structural funds and the Cohesion Fund. Managing authorities are responsible both for the preparation and implementation of programmes, which includes control and monitoring as well as preparation of criteria for selecting projects. Managing authorities may delegate some of the tasks to intermediate bodies that belong to the public finance sector. Intermediate bodies may perform numerous operational actions connected with the implementation of programmes stipulated in a contract or agreement. They may also delegate some of their tasks to other bodies, called the second level intermediate bodies, by means of contract or agreement. Another important role in the implementation system is played by the certification body (also the Minister of Regional Development) responsible for the certification of expenditure incurred from structural funds and the Cohesion Fund, and the audit body in the person of the General Inspector of Fiscal Control at the Ministry of Finance. Pursuant to Article 28 Paragraph 1 of the Act, bodies authorised to implement financial instruments or funds of funds include the bodies mentioned in Article 38 Paragraph 4 Subparagraphs $\mathrm{a}$ and $\mathrm{b}$ of the General Regulation, in particular, Bank Gospodarstwa Krajowego, National Fund for Environmental Protection and Water Management, and Polish Agency for Enterprise Development.

When it comes to the Convergence Objective, the cohesion policy may be described as a tool for stimulating development investments e. g. by overcoming development barriers. As regards the Regional Competitiveness and Employment Objective, the cohesion policy is said to have unblocked development processes (Molle 2015, 108). Nevertheless, it is operational programmes that are the basic instruments for implementing the cohesion policy:

- Operational Programme Infrastructure and Environment - co-financed by the ERDF and the Cohesion Fund,

- Operational Programme Innovative Economy - co-financed by the ERDF,

- Operational Programme Human Capital - co-financed by the ESF,

- Sixteen Regional Operational Programmes - financed by the ERDF,

- Operational Programme Development of Eastern Poland - financed by the ERDF,

- Operational Programme Technical Assistance - financed by the ERDF,

- Operational Programmes European Territorial Cooperation - financed by the ERDF.

It must be pointed out that the cohesion policy concentrates on a limited number of objectives, that is investments aimed at economic growth, employment, and European territorial cooperation. Due to the fact that the financial aid comes from the EU, member states, including Poland, are obliged to spend the funds on particular investments in regions, taking into account the level of their development. The central premise of the cohesion policy is, therefore, economic growth achieved through particular investments, 
e.g. implementation of the strategic priorities of the new strategy Europe 2020 (smart, sustainable, and inclusive growth). The particularly supported areas include research and innovation, SMEs, low emission economy. However, the number of funds allocated to given areas of the economy will differ depending on the region category. Member states concentrate on a limited number of objectives which they adapt to existing conditions (Kozak 2011, 8).

2.2.2. Polish Agency for Enterprise Development as an implementing body. The Polish Agency for Enterprise Development provides financial aid to entrepreneurs whose businesses are innovative and based on research. The Agency also supports regional development, human resources development, and the use of new technology. The legal basis for the scope of the Agency's activity is the Act on the establishment of the Polish Agency for Enterprise Development (The Act of 9 November 2000. Journal of Laws from 2018, item 110). According to the legislator, the Agency is to perform government administration tasks described in programmes of economic growth. The tasks involve, in particular, supporting: 1) entrepreneurs and microentrepreneurs, small and medium entrepreneurs, and persons willing to start a business activity, 2) export, 3) regional development, 4) innovative enterprise as stipulated in the Act of 29 July 2005 on some forms of supporting innovative enterprise (Journal of Laws No. 179, item 1484 and from 2006 No. 107, item 723), 5) creation of new jobs, unemployment prevention, development of human resources, development of the adaptation potential of entrepreneurs. In addition, the Agency participates in implementing operational programmes mentioned in the Act of 20 April 2004 on National Development Programme (Journal of Laws No. 116, item 1206 as amended) and the Act of 6 December 2006 on principles of development policy implementation (Journal of Laws No. 227, item 1658 and from 2007 No. 140, item 984) as an implementing body (second level intermediate body) or an intermediate body providing financial aid to certain beneficiaries, or as a beneficiary. The legislator has not prepared a coherent list of tasks to be performed by the Agency. There are only exemplary tasks and an expression "in particular". Thus the list of tasks is open. Nevertheless, the detailed scope of tasks performed by the Agency is stipulated in its statute and organizational regulations.

The tasks performed by the agency can be divided according to their subject. There are three groups of tasks: organizational and informational, supportive and financial, and of programme character. However, the Agency is, above all, responsible for implementing actions within the framework of three operational programmes: Smart Growth, Development of Eastern Poland, and Knowledge Education Development.

The Operational Programme Smart Growth provides entrepreneurs with the biggest amount of funds. The Programme's budget is EUR 8.61 billion. The Polish Agency for Enterprise Development is responsible for implementing selected instruments within the framework of priority axes II and III of the Programme. The main areas of the Agency's activities related to the Programme include development of innovative entrepreneurship, investment in innovation, start-up market, and internationalization of companies. It is particularly planned to provide support within the framework of the following measures: Pro-innovative services for enterprises, Cooperation within the framework of the national innovation system; Increased funding of the SME innovative activity using venture capital; Support for R\&D results implementation; Support for promotion and internationalization of innovative enterprises. 
As regards the Operational Programme Eastern Poland, its main objective is to boost competitiveness and innovativeness of the Eastern Poland region comprising of five voivodeships with the lowest GDP per capita in Poland and one of the lowest in the EU: Warmińsko-Mazurskie, Podlaskie, Lubelskie, Podkarpackie i Świętokrzyskie. The amount of funds intended for the Programme is EUR 2 billion. The Polish Agency for Enterprise Development acts as an implementing body of the Programme. The Agency has the following support instruments at its disposal: start-up platforms for new ideas, startup development in Eastern Poland, internationalization of SMEs, a creation of network products by SMEs, competition design, and road infrastructure (http://popw.parp.gov.pl/ attachments/article/36727/2015_07_06_Strategia_komunikacji_POPW.pdf).

When it comes to the Operational Programme Knowledge Education Development, the Polish Agency for Enterprise Development is to undertake actions aimed at adapting employees competence to the needs of the job market. It is a reaction to the major challenge the Polish job market is now facing: unfavourable demographic trends, fewer and fewer people at working age, and recruitment problems faced both by employers and job seekers. According to the information from the Polish Agency for Enterprise Development, the agreement between the Ministry of Economy and the Agency on entrusting the latter with the role of an Implementing Body responsible for implementing particular actions of the Operational Programme Smart Growth is under discussion. The main areas of the Agency's activities regarding the OPSG include the development of innovative entrepreneurship, investments in innovation, start-up market, and internationalization of enterprises.

It must be stressed, however, that in the new financial perspective for the years 20142020 the Polish Agency for Enterprise Development has been obliged to continue implementing the Operational Programme Eastern Poland from the years 2007-2013. The aim of that programme is to boost competitiveness and innovativeness of the Eastern Poland macroregion, that is five voivodeships (Warmińsko-Mazurskie, Podlaskie, Lubelskie, Podkarpackie i Swiętokrzyskie) with the lowest GDP per capita in the country and one of the lowest in the EU.

\section{Conclusions}

To conclude, it must be emphasized that the actions member states take to obtain EU funds can be divided into two categories: central and regional (Wojczyńska 2007, 8). In the case of the former, the legislator and central administration are involved in preparing and passing appropriate legal solutions, and implementing and preparing mechanisms both at central and regional levels. As regards the latter, regions are obliged to build new administrative apparatus and establish cooperation between local government units.

The adoption of the EU legal order, as well as requirements regarding the functioning of institutions responsible for implementing tasks in the area of the economy (e.g. Polish Agency for Enterprise Development), contributed to the significant growth of Polish economy. According to the report "10 years in the UE" (http://ec.europa.eu/polska/news/ documents/10lat_plwue.pdf), Polish accession to the EU has exerted an immense influence on export which has become one of the major stimuli of the Polish economic growth.

During that period the amount of exported goods increased by $170 \%$ with the biggest participation of food and agricultural industry. The Europe Agreement between the EU 
and Poland became an impulse to take some adaptation initiatives also in non-statutory areas of the Polish economy such as the efficient functioning of commercial courts or preventing corruption (Nowak-Far 2010, 433). The 2014-2020 budget negotiations are considered to have been the most significant and difficult political achievements of Poland since it joined the EU. One should bear in mind, however, that the funds obtained for those seven years are to contribute to the stabilization of the economy, the food and agricultural market, and the state policy. Beneficiaries have an opportunity to obtain those funds owing to institutions such as government implementing agencies.

In our opinion, adjusting to EU regulations should be considered in several perspectives. Everything depends on the attitude towards the European Union itself as an institution. The Union's actions are not always taken as the "voice" of all Member States. Sometimes it is the voice of a "stronger" Member State that imposes on others adapting to its vision of cooperation. Therefore, the legal and actual (economic and social) situation of a given country is not always taken into account. This country must adapt itself, by introducing legal provisions into its own legal system and creating, if necessary, a specific entity. As a consequence, a given legislator is forced to create a subject that differs from the characteristics of a subject identified as typical by its characteristics. We can, therefore, speak of a kind of europeanization of law, in particular of administrative law. The term europeanization of law should be understood as dissemination of civilizational and cultural achievements specific to the European continent outside Europe (Wołpiuk 2008). The europeanization of administrative law can also be understood as adapting the content of the provisions to the requirements in force in European Union countries. When interpreting the concept of europeanization one should not lose sight of the issues of the application of the provisions, that is their practical implementation. However, it is not always associated with the European Union, or europeanization must mean something right, which we can use uncritically.

The subject of the article's analysis was specific entities of public administration in Poland. The attention was focused on government agencies that were created as a result of the impact of EU legislation on Poland. As it has been shown, EU law has influenced and continued to affect the scope of their activities, tasks performed and the method of spending EU funds entrusted to them.

It is true that the impact of EU law is very significant on the operation of government agencies and how they perform their tasks. However, as regards the enforcement of individual rights that are related to the implementation of tasks by agencies, it should be stressed that the proceedings are of administrative nature and are based on national law. Consequently, the proceedings shall be entitled to appeal against the decision issued by the Agency to the administrative body and appeal to the administrative courts (voivodship administrative court and the Supreme Administrative Court). There is also the possibility of filing a cassation appeal to the Supreme Administrative Court for the Court to apply the "legal question" to the Court of Justice of the European Union based in Luxembourg for a specific interpretation of legal provisions.

\section{References}

Boć, Jan. 2003. Prawo administracyjne, edited by J. Boć. Wrocław.

Bieś-Srokosz, Paulina. 2016. Uagencyjnianie administracji publicznej — przykład procesu tworzenia agencji rządowych w Polsce, Współczesne kierunki zmian administracji publicznej, edited by P. Bieś-Srokosz. Częstochowa. 
Bieś-Srokosz, Paulina. 2018. Tendencje zmian prawnych form realizacji zadań publicznych, Prawo administracyjne dziś i jutro, edited by J. Jagielski, M. Wierzbowski. Warszawa.

Borkowski, J. 1972. Pojęcie władztwa administracyjnego, Acta Universitatis Wratislaviensis no 167, „Przegląd Prawa i Administracji" no 31. Wrocław.

Chamon, M. 2010. EU agencies: does the "Meroni" doctrine make sense? Maastricht Journal of European and Comparative Law, v. 17, no. 3.

Jagielski, Jacek, Wierzbowski, Marek, Wiktorowska, Aleksandra. 2005. Nietypowe podmioty administrujące - kilka refleksji na tle organizacyjnych form wykonywania zadań publicznych, Podmioty administracji publicznej i prawne formy ich działania. Studia i materiały z konferencji jubileuszowej Profesora Eugeniusza Ochendowskiego. Toruń.

Jendrośka, Jan. 1963. Zagadnienia prawne wykonania aktu administracyjnego. Wrocław.

Kasznica, Stanisław. 1943. Polskie prawo administracyjne. Pojęcia i instytucje zasadnicze. Warszawa.

Knosala, Ernest. 2007. Zadania publiczne, formy organizacyjnoprawne ich wykonywania i nowe pojęcia zakres niektórych problemów do dyskusji nad koncepcją systemu prawa administracyjnego. Koncepcja systemu prawa administracyjnego, edited by J.Zimmermann. Kraków.

Kozak, Marek. 2011. Polityka spójności - wyzwania, Polityka spójności w okresie 2014-2020 a rozwój regionów Europy, edited by E. Pancer-Cybulska, E. Szostak. Wrocław.

Longchamps, de Bérier, Franciszek. 1968. Prawo administracyjne i wiedza o nim. Wrocław.

Longchamps, de Bérier, Franciszek. 1991. Założenia nauki administracji. Wrocław: Wydawn. Uniwersytetu Wrocławskiego.

Maurer, Hartmut. 2003. Ogólne prawo administracyjne. Allgemeines Verwaltungsrecht, edited by K. Nowacki. Wrocław.

Mikos-Sitek, A. 2012. „Wieloletni Plan Finansowy Państwa oraz wieloletnia prognoza finansowa jednostki samorządu terytorialnego - nowe instrumenty wieloletniego planowania finansowego", Edukacja Prawnicza, no. 3 .

Molle, Willem. 2015. Cohesion and Growth. The Theory and Practice of European Policy Making, Routledge. London \& New York.

Nowak-Far, Artur. 2010. Ewolucja prawodawstwa gospodarczego, Transformacja systemowa w Polsce, edited by K. Żukrowska. Warszawa.

Pawłowicz, K.2001. Nietypowe podmioty administrujące w sferze gospodarki, Prawo gospodarcze. Zagadnienia administracyjnoprawne, edited by M. Wierzbowski, M. Wyrzykowski. Warszawa.

Pulka, Z.1992. Władztwo administracyjne jako szczególna postać władzy państwowej, Acta Universitatis Wratislaviensis no 1313, Prawo CCVI. Wrocław.

Rabska, Teresa. 1977. Podstawowe pojęcia organizacji administracji. System prawa administracyjnego, edited by J.Starościak. Wrocław.

Rabska, Teresa. 1990. Prawny mechanizm kierowania gospodarką. Działalność prawodawcza administracji i jej uwarunkowania. Wrocław-Warszawa-Kraków.

Stahl, M. 2011. Zagadnienia ogólne. Podmioty administrujące, System prawa administracyjnego, t. VI, edited by R. Hausner, Z. Niewiadomski, A. Wróbel. Warszawa.

Trzciński, Janusz. 2005. Rzeczypospolita dobrem wspólnym wszystkich obywateli. Sadownictwo administracyjne gwarantem wolności i praw obywatelskich 1980-2005, edited by J. Góral, R. Hauser, J. Trzciński. Warszawa.

Wojczyńska, A. 2007. „Zasady i system zarządzania środkami strukturalnymi przeznaczonymi na rozwój regionalny", Edukacja Prawnicza 2007, no. 1.

Wołpiuk, Waldemar. 2008. „Semantyczne, prawne i konstytcyjnoprawne aspekty pojęcia europeizacji”, Zeszyty Naukowe Wyższej Szkoły Zarzadzania i Prawa im. Heleny Chodkowskiej w Warszawie, no. 7.

Zimmermann, Jan. 2006. Prawo administracyjne. Kraków.

Received: March 22, 2018 Accepted: August 15, 2018

Authors' information:

Paulina Bieś-Srokosz — PhD, Professor; PaulinaBiesSrokosz@interia.pl

Mariia A. Kapustina - PhD, Associate Professor; m.kapustina@spbu.ru 